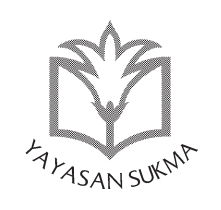

SUKMA: JURNAL PENDIDIKAN

ISSN: 2548-5105 (p), 2597-9590 (e) Volume 4 Issue 1, Jan-Jun 2020, pp. 73-88 https://doi.org/10.32533/04204.2020 www.jurnalsukma.org

\title{
KEPEMIMPINAN KEPALA SEKOLAH DAN KINERJA GURU Kasus di SDIT Cahaya Sunnah Cileungsi Bogor
}

\section{Mukhadasin}

Universitas Islam 45 Bekasi, Indonesia

email:mukhadasin@gmail.com

\section{Aos Kuswandi}

Universitas Islam 45 Bekasi, Indonesia

email:aos_kuswandi@unismabekasi.ac.id

\section{Abstract}

Penelitian ini bertujuan untuk mengetahui gaya kepemimpinan Kepala Sekolah Dasar Islam Terpadu (SDIT) Cahaya Sunnah Cileungsi Kabupaten Bogor dalam upaya peningkatan kinerja guru. Teknik Pengambilan data melalui observasi, wawancara, dan dokumentasi. Informan dipilih secara purposive sampling sesuai 
dengan pertimbangan dan kepentingan data/informasi yang diperlukan. Hasil penelitian ini menyimpulkan bahwa, pertama, gaya kepemimpinan yang dijalankan oleh kepala SDIT Cahaya Sunnah Cileungsi cenderung pada kepemimpinan transformasional. Hal ini terlihat pada indikator-indikator gaya kepemimpinan transformasional yang terdapat pada gaya kepemimpinan kepala sekolah. Kedua, kinerja guru dalam kaitannya dengan perencanaan proses belajar mengajar masih rendah. Ketiga, langkah-langkah yang dilakukan kepala sekolah dalam meningkatkan kinerja guru di antaranya adalah dengan melibatkan warga sekolah dalam penyusunan visi, misi, dan program sekolah, mengadakan pelatihan-pelatihan yang dilakukan secara berkala, pendekatan personal, pembinaan, pemberian bonus, reward, dan punishment.

Keywords: gaya kepemimpinan, kepala sekolah, kinerja guru.

\section{A. Pendahuluan}

Kepala sekolah dan guru dalam institusi pendidikan sangat menentukan sukses tidaknya pelaksanaan pendidikan dan pembelajaran. Perannya dalam pengembangan sekolah ditentukan oleh kemampuan manajemen kepemimpinan dalam pelaksanaan tugas yang dibebankan kepadanya. Tidak jarang kegagalan proses pendidikan dan pembelajaran di sekolah disebabkan oleh kurangnya pemahaman kepala sekolah terhadap tugas-tugas yang harus dilaksanakannya. Kondisi tersebut menunjukkan bahwa berhasil tidaknya suatu sekolah dalam mencapai tujuan serta mewujudkan visi dan misinya terletak pada bagaimana manajemen dan kepemimpinan kepala sekolah, khususnya dalam menggerakkan dan memberdayakan berbagai komponen sekolah (Mulyasa 2013).

Selain kepemimpinan kepala sekolah, kinerja guru di dalam suatu sekolah juga sangat memiliki peran penting seka- 
ligus pengaruh besar terhadap mutu sekolah tersebut. Guru merupakan salah satu faktor penentu tinggi rendahnya mutu hasil pembelajaran di suatu sekolah. Guru dituntut memiliki kinerja yang mampu merealisasikan cita-cita dan harapan masyarakat yang telah menitipkan putra putrinya untuk dibina dan didik olehnya. Untuk menjadi guru diperlukan syarat-syarat khusus, apalagi sebagai guru yang professional yang harus menguasai betul seluk beluk pendidikan dan pengajaran dengan berbagai ilmu pengetahuan lainnya yang perlu dibina dan dikembangkan melalui masa pendidikan tertentu atau pendidikan prajabatan (Usman, 2014).

Salah satu sekolah Islam yang sedang berkembang di wilayah Kecamatan Cileungsi Kabupaten Bogor adalah Sekolah Dasar Islam Terpadu (SDIT) Cahaya Sunnah. Berdasarkan observasi awal ditemukan bahwa kinerja guru di sekolah ini sedang mengalami kemunduruan. Selain itu, pengamat juga menemukan bahwa sejak berdirinya pada tahun 2012, SDIT Cahaya Sunnah sudah mengalami proses pergantian kepala sekolah sebanyak 3 kali. Pergantian terakhir adalah pada tahun 2016. Sebelum pergantian kepala sekolah yang terakhir tersebut, keadaan tenaga kependidikan di SDIT Cahaya Sunnah menunjukan kurang disiplin. Sejak pergantian kepala sekolah yang ketiga ini pun, kinerja guru belum begitu mengalami kemajuan yang signifikan. Bahkan berdasarkan penelusuran awal peneliti, guru yang mengerjakan administrasi guru belum mencapai 30\% (Dokumentasi SDIT Cahaya Sunnah Cileungsi 2019).

Terdapat fakta di lapangan yang menunjukkan masih rendahnya kinerja guru. Wawancara awal yang dilakukan terhadap lima guru secara acak mengindikasikan akan rendahnya kinerja guru. Hasil wawancara menunjukkan beberapa gambaran mengenai kondisi yang dimaksud, antara lain: mayoritas guru tidak membuat perencanaan yang memadai dalam menjalankan tugas mengajar, tidak menyusun RPP, membuat RPP hanya untuk memenuhi syarat administrasi mengajar dan tidak mempersiapkan media pembelajaran dengan baik. Mayoritas guru juga mengajar hanya dengan acuan buku, tidak memiliki pedoman 
berupa RPP yang baik dalam mengajar. Akhirnya pembelajaran tidak terarah, sering kali juga materi belum selesai padahal waktu ujian sudah tiba. Efek dari hal tersebut juga adalah para peserta didik tidak memperoleh materi secara maksimal.

Kepemimpinan seseorang akan dapat menggerakkan bawahannya untuk berbuat yang terbaik untuk organisasinya. Disinilah pentingnya peran kepala sekolah dalam sebuah lembaga pendidikan untuk meningkatkan kinerja guru. Kenyataan yang ditemukan oleh peneliti melalui observasi dan wawancara awal dengan tiga guru kelas diperoleh informasi bahwa kepala sekolah sudah menjalankan kepemimpinannya dengan sedemikian rupa. Namun, perlu adanya peningkatan dan upaya memaksimalkan pelaksanaanya oleh kepala sekolah, yang pada akhirnya bisa mempengaruhi kinerja guru yang ada di sekolah.

Berdasarkan uraian di atas maka penelitian yang dilakukan fokus pada Gaya Kepemimpinan Kepala Sekolah dalam Meningkatkan Kinerja Guru di Sekolah Dasar Islam Terpadu (SDIT) Cahaya Sunnah Cileungsi Kabupaten Bogor. Penelitian ini menggunakan metode penelitian deskriptif kualitatif. Penggunaan pendekatan deskriptif dengan tujuan untuk mendeskripsikan objek penelitian ataupun hasil penelitian. Deskriptif adalah metode dalam meneliti suatu kelompok, suatu obyek. suatu kondisi, suatu sistem, suatu pemikiran atau kelas peristiwa pada masa sekarang (Nasir 1993).

Sumber data dalam penelitian adalah subyek dari mana data dapat diperoleh (Arikunto 2010). Dalam penelitian kualitatif ini, peneliti mencari data dengan melakukan observasi kata-kata dan perilaku orang-orang yang ada dalam obyek, kemudian sebagian diwawancarai dan didokumentasikan yang merupakan sumber data utama dan dicatat melalui catatan tertulis atau melalui perekaman audio tapes, pengambilan foto dan lain-lain (Nasution 2003,112). Sumber data primer dalam penelitian ini diperoleh dari informan sebanyak 15 orang yang terdiri atas kepala sekolah, wakil kepala sekolah, guru dan karyawan (Suryabrata 1987, 44). 
Adapun sumber data sekunder yang digunakan dalam penelitian ini adalah berupa dokumentasi seperti foto-foto, buku binaan, kurikulum, Tata Tertib, daftar guru dan siswa, serta beberapa data penting sekolah yang didapat dari staf TU.

Agar diperoleh data yang valid dalam kegiatan penelitian ini maka perlu ditentukan teknik-teknik dalam pengumpulan data yang sesuai dan sistematis. Dalam hal ini peneliti menggunakan teknik-teknik dalam pengumpulan data kuantitatif di antaranya adalah adalah wawancara, dokumentasi, dan observasi. Berdasarkan data yang telah terkumpul kemudian dilakukan analisis data secara deskriptif yaitu dengan cara memaparkan secara objektif dan sistematis situasi yang ada di lapangan. Penulis menggunakan analisa data kualitatif, dimana data yang diperoleh dianalisa dengan metode deskriptif dengan cara berfikir induktif yaitu penelitian dimulai dari fakta-fakta yang bersifat empiris dengan cara mempelajari suatu proses, suatu penemuan yang terjadi, mencatat, menganalisa, menafsirkan, melaporkan serta menarik kesimpulan dari proses tersebut.

\section{B. Studi Tentang Kepemimpinan Sekolah}

Menurut Sadili Samsudin, kepemimpinan adalah kemampuan meyakinkan dan menggerakkan orang lain agar mau bekerja sama di bawah kepemimpinannya sebagai satu tim untuk mencapai satu tujuan (Samsudin 2006). Menurut Usman Effendi fungsi kepemimpinan ialah memandu, menuntun, membimbing, membangun, memberi motivasi kerja, mengarahkan organisasi, menjalin jaringan komunikasi yang baik, memberikan pengawasan yang efisien, dan membawa para pengikutnya kepada sasaran yang ingin dicapai sesuai dengan target dan perencanaan. Agar kelompok berjalan dengan efektif, pemimpin harus melaksanakan fungsi utama, yaitu; a) Fungsi yang berhubungan dengan tugas atau pemecahan masalah yaitu menyangkut pemberian saran penyelesaian, informasi dan pendapat.. b) Fungsi-fungsi pemeliharaan kelompok atau sosial yaitu segala sesuatu yang dapat membantu kelompok berjalan lebih lancar persetujuan 
dengan kelompok lain, penengahan perbedaan kelompok dan sebagainya (Effendi 2011).

Kepala sekolah sebagai pemimpin di sekolah berperan sebagai orang yang menjadi penggerak di setiap aktivitas warga sekolahnya dan dituntut untuk mampu membuat keputusan ataupun kebijakan demi tercapainya tujuan sekolah. Kepala sekolah sebagai pemimpin dalam organisasi sekolah memiliki beberapa peran sebagai manajer, administrator, leader, educator, dan supervisor. Peran-peran tersebut lah yang akan dijadikan sebagai fokus kajian oleh penulis dalam penelitian ini.

Aktivitas kepala sekolah sebagai seorang manajer meliputi pengelolaan $3 \mathrm{M}$, yaitu pertama, manusia sebagai faktor penggerak utama aktivitas sekolah, kedua, money yaitu sebagi modal aktivitas, ketiga, method sebagai alat untuk mengarahkan manusia dan uang menjadi efektif dalam mencapai tujuan (Mulyasa 2001).

Kepala sekolah sebagai administrator pendidikan penanggung jawab terhadap kelancaran pelaksanaan pendidikan pengajaran di sekolahnya oleh karena itu, untuk dapat melaksanakan tugasnya dengan baik, kepala sekolah hendaknya memahami, menguasai dan mampu melaksanakan fungsi sebagai administrator pendidikan. Kepala sekolah sebagai administrator hendaknya mampu melaksanakan kegiatan-kegiatan yang berkenaan dengan fungsinya sebagai adnimistrasi pendidikan dengan masyarakat (Soetjipto dan Kosasih 2009).

Menurut Fread E. Fidler pemimpin adalah individu di dalam kelompok yang memberikan tugas-tugas, pengarahan dan pengorganisasian yang relevan dengan kegiatan-kegiatan kelompok (Purwanto 2005, 27). Hal ini jika dikaitkan dengan pendidikan orang yang ditunjuk menjadi pimpinan (leader) sebuah lembaga pendidikan yang memberikan tugas-tugas, mengkoordinasi dan pengawasan sesuai dengan kegiatan-kegiatan kependidikan.

Sebagai educator, kepala sekolah harus memiliki strategi yang tepat untuk meningkatkan profesionalisme tenaga kependidikan di sekolahnya yaitu dengan menciptakan iklim sekolah 
yang kondusif, memberikan nasihat kepada warga sekolah, memberikan dorongan kepada seluruh tenaga kependidikan, serta melaksanakan model pembelajaran yang menarik. Kepala sekolah sebagai seorang pendidik (educator) juga harus mampu menanamkan mental dan moral (akhlak dan budi pekerti) kepada warga sekolah.

Salah satu tugas kepala sekolah adalah sebagai supervisor, yaitu mensupervisi pekerjaan yang dilakukan oleh tenaga kependidikan. Supervisi merupakan suatu proses yang dirancang secara khusus untuk membantu para guru dan supervisor dalam mempelajari tugas sehari-hari di sekolah agar dapat menggunakan pengetahuan dan kemampuannya untuk memberikan layanan yang lebih baik pada orang tua, peserta didikm dan sekolah, serta berupaya menjadikan sekolah sebagai masyarakat belajar yang lebih efektif (Mulyasa 2013, 252). Lebih lanjuta Mulyasa menjelaskan bahwa peran kepala sekolah sebagai supervisor dapat dilakukan secara efektif antara lain melalui diskusi kelompok, kunjungan kelas, pembicaraan individual, dan simulasi pembelajaran (Mulyasa 2013, 254).

Penilaian kinerja penting dilakukan oleh suatu sekolah untuk perbaikan kinerja guru itu sendiri maupun untuk sekolah dalam hal menyusun kembali rencana atau strategi baru untuk mencapai tujuan pendidikan nasional. Penilaian yang dilakukan dapat menjadi masukan bagi guru dalam memperbaiki dan meningkatkan kinerjanya. Selain itu penilaian kinerja guru membantu guru dalam mengenal tugas-tugasnya secara lebih baik sehingga guru dapat menjalankan pembelajaran seefektif mungkin untuk kemajuan peserta didik dan kemajuan guru sendiri menuju guru yang profesional. Sedangkan seorang guru yang profesional dituntut memiliki perencanaan dalam proses pembelajaran yang akan dijalankannya. Karena keberhasilan dari kegiatan pembelajaran sangat ditentukan oleh perencanaannya. Perencanaan proses pembelajaran dapat diartikan sebagai suatu proses kegiatan merumuskan tujuan-tujuan apa yang ingin dicapai oleh suatu kegiatan pembelajaran, cara apa yang digunakan untuk menilai pencapaian tujuan tersebut, materi atau 
bahan apa yang akan disampaikan, bagaimana cara menyampaikan bahan serta media atau alat apa yang diperlukan untuk mendukung pelaksanaan pembelajaran tersebut (Mulyasa 2007, 2016).

Merujuk pada peraturan Menteri Pemberdayaan Aparatur Negara No. 16 Tahun 2009, maka indikator penilaian kinerja guru dapat disimpulkan menjadi lima yaitu: (1) menguasai bahan ajar (2) merencanakan proses belajar mengajar (3) kemampuan melaksanakan dan mengelola proses belajar mengajar, (4) kemampuan melakukan evaluasi atau penilaian, dan (5) kemampuan melaksanakan bimbingan belajar (perbaikan dan pengayaan).

Menurut penelitian yang dilakukan oleh Wahyu Ramadoni, Kusmintardjo Kusmintardjo, dan Imron Arifin tentang "Kepemimpinan Kepala Sekolah dalam Upaya Peningkatan Kinerja Guru (Studi Multi Kasus di PAUD Islam Sabilillah dan SDN Tanjungsari 1 Kabupaten Sidoarjo)", dihasilkan bahwa gaya kepemimpinan kepala sekolah yang diterapkan oleh kepala sekolah PAUD Islam Sabilillah dan SDN Tanjungsari 1 Kabupaten Sidoarjo mempengaruhi kinerja guru karena kepala sekolah menerapkan kedisiplinan, dari kedisiplinan bisa memberikan pembelajaran kepada seluruh warga sekolah (guru, siswa dan pegawai) untuk menjadi lebih baik lagi kedepannya. Kepala sekolah juga bersikap demokratis, memberikan ruang kepada guru untuk bekerja dan memahami setiap perbedaan karakter dari setiap individu guru yang bertujuan untuk menempatkan kepemimpinannya dari guru satu ke guru lainnya. Kemudian kepala sekolah menerapkan komunikasi yang baik, dari komunikasi yang baik kepada warga sekolah maka segala bentuk program sekolah dan tugas lainnya bisa sesuai tujuan (Romdani dkk 2019).

Hal serupa juga dikuatkan dengan hasil penelitian yang dilakukan oleh Menurut penelitian yang dilakukan oleh Liasrawati, Zakaria, dan Puspa Djuwita berkaitan dengan "Peran Kepemimpinan Kepala Sekolah dalam Meningkatkan Kinerja Guru Bahasa Inggris", dihasilkan bahwa kepemimpinan kepala sekolah yang 
Kepemimpinan Kepala Sekolah dan Kinerja Guru

dilaksanakan dengan baik akan berperan dalam meningkatkan kinerja guru bahasa Inggris. Hasil spesifiknya adalah guru bahasa Inggris dapat melakukan proses belajar mengajar dengan baik, kompetensi guru bahasa Inggris meningkat, dan kualitas kerja guru bahasa Inggris terus dilakukan (Liasrawati, Zakaria, and Djuwita 2017).

\section{Kepemimpinan Kepala Sekolah SDIT Cahaya Sunnah Cileungsi}

Kepala sekolah merupakan pucuk pimpinan yang ada di sekolah dan memiliki peran sangat penting dalam maju tidaknya suatu sekolah. Kepala sekolah diharuskan memiliki kiat-kiat yang tepat untuk bisa meningkatkan kinerja guru di sekolahnya. Perannya tersebut dibutuhkan agar visi, misi, serta tujuan pendidikan di sekolahnya bisa terwujud dan terealisasi. Kepala sekolah telah menjalankan perannya sebagai manajer di sekolah dengan merencanakan, mengorganisasikan, memimpin, mengendalikan, dan menggerakkan anggota-anggota serta seluruh sumber daya organisasi dalam rangka mencapai tujuan yang telah ditetapkan. Kepala sekolah juga melibatkan seluruh tenaga kependidikan dalam penyusunan program, visi dan misi sekolah. Program kepala sekolah disusun sebagai acuan dalam meningkatkan kompetensi guru, yang dilaksanakan dalam pemberdayaan guru-guru. Program pemberdayaan guru-guru dilaksanakan dengan mengikutsertakan guru dalam pengambilan keputusan sekolah dan juga melatih guru-guru untuk bertanggungjawab dalam pengembangan sekolah Kepala sekolah dalam merumuskan programnya mengikutsertakan semua guru dan staf sekolah (Purwanti, Murniati A. R., and Yusrizal 2014).

Peran kepala sekolah sebagai administrator diwujudkan dengan menyediakan, mengatur, dan melengkapi fasilitas, sarana dan prasarana sekolah demi terwujudnya pembelajaran yang baik. Kepala sekolah juga senantiasa melakukan pemeliharaan terhadap fasilitas yang ada dengan melakukan koordinasi dan sosialisasi dengan warga sekolah, baik itu guru, karyawan, 
maupun para peserta didik. Kepala sekolah menanamkan nilai-nilai kedisiplinan dan rasa memiliki kepada mereka terhadap sarana dan prasarana yang ada di sekolah. Menurut Soetjipto dan Raflis Kosasi, kepala sekolah sebagai administrator pendidikan penanggung jawab terhadap kelancaran pelaksanaan pendidikan pengajaran di sekolahnya oleh karena itu, untuk dapat melaksanakan tugasnya dengan baik, kepala sekolah hendaknya memahami, menguasai dan mampu melaksanakan fungsi sebagai administrator pendidikan. Kepala sekolah sebagai administrator hendaknya mampu melaksanakan kegiatan-kegiatan yang berkenaan dengan fungsinya sebagai adnimistrasi pendidikan dengan masyarakat (Soetjipto and Kosasi 2009, 192).

Kepala sekolah menjalankan perannya sebagai leader (pemimpin) dalam lembaganya dengan memberikan semangat dan percaya diri para guru, karyawan dan peserta didik. Beliau juga memberikan bimbingan, dan inspirasi kepada mereka demi mencapai tujuan bersama. Hal tersebut sejalan dengan pendapat Wahjosumidjo ketika menjelaskan tentang peran kepala sekolah sebagai seorang leader (pemimpin). Beliau menjelaskan bahwa kepala sekolah harus mampu mendorong timbulnya kemauan yang kuat dengan penuh semangat dan percaya diri para guru, staf dan siswa dalam melaksanakan tugas masing-masing. Kemudian kepala sekolah juga harus bisa memberikan bimbingan dan mengarahkan para guru, staf dan para siswa serta memberikan dorongan memacu dan berdiri di depan demi kemajuan dan memberikan inspirasi sekolah dalam mencapai tujuan (Wahjosumidjo 2007, 105).

Peran kepala sekolah sebagai educator (pendidik) direalisasikan dengan membentuk strategi yang tepat untuk meningkatkan profesionalisme tenaga kependidikan di sekolahnya. Kepala sekolah juga berusaha menciptakan iklim sekolah yang kondusif, memberikan nasihat dan binaan kepada warga sekolah, menjadi panutan juga dalam pemberian motivasi/ dorongan kepada seluruh tenaga kependidikan, serta menanamkan mental dan moral (akhlak dan budi pekerti) kepada warga sekolah. Menurut Wahjosumidjo, kepala sekolah sangat berperan 
Kepemimpinan Kepala Sekolah dan Kinerja Guru

dan menjadi sumber motivasi yang kuat terhadap keberhasilan ketiga organisasi tersebut. Secara singkat keberadaan ketiga organisasi tersebut dirasa penting dan diperlukan dalam rangka pembinaan sekolah yaitu: organisasi orang tua peserta didik, organisasi peserta didik, dan organisasi guru (Wahjosumidjo 2009, 81).

Peran kepala sekolah sebagai supervisor diwujudkan dengan melakukan supervisi terhadap pekerjaan yang dilakukan oleh tenaga kependidikan. Supervisi diwujudkan dengan kunjungan kelas, pembicaraan individual, dan simulasi pembelajaran. Semua itu dilakukan untuk membantu para guru dalam menjalankan tugas kesehariannya sebagai seorang guru. Supervisi yang dilakukan oleh kepala sekolah sudah sesuai dengan yang disampaikan oleh H.E. Mulyasa, yang mana beliau berpendapat bahwa peran kepala sekolah sebagai supervisor dapat dilakukan secara efektif antara lain melalui diskusi kelompok, kunjungan kelas, pembicaraan individual, dan simulasi pembelajaran (Mulyasa 2013, 254).

\section{Kinerja Guru SDIT Cahaya Sunnah Cileungsi}

Para guru telah mempersiapkan bahan ajar sebelum mengajar. Bahan ajar yang digunakan adalah buku paket pegangan guru yang didapatkannya dari sekolah. Mereka melakukan hal tersebut dengan tujuan agar maksimal ketika memberikan materi kepada peserta didik. Menurut Ali Mudlofar bahan ajar adalah segala bentuk bahan yang digunakan untuk membantu guru/instruktur dalam melaksanakan kegiatan belajar mengajar di kelas. Bahan yang dimaksud bisa berupa bahan tertulis maupun tidak tertulis (Mudhofar 2012, 128).

Berkaitan dengan perencanaan proses belajar mengajar, para guru belum menjalankannya dengan baik. Hasil penelitian menunjukkan bahwa banyak di antara guru yang tidak membuat perangkat administrasi guru berupa Rencana Pelaksanaan Pembelajaran (RPP), alhasil pembelajaran berjalan tanpa perencanaan yang matang. Padahal kepala sekolah dan wakil kepala 
sekolah bagian kurikulum sudah mencanangkan program terkait kewajiban membuat administrasi. Menurut Manshur Muslich, Rencana pelaksanaan pembelajaran (RPP) merupakan rancangan mata pelajaran per unit yang akan ditetapkan guru dalam pembelajaran di kelas. Berdasarkan RPP inilah seorang guru baik yang menyusun RPP itu sendiri maupun yang bukan diharapkan bisa menerapkan pembelajaran secara terprogram. Pada sisi lain, melalui RPP pun dapat diketahui kadar kemampuan guru dalam menjalankan profesinya (Muslich 2008, 45).

Berkaitan dengan pelaksanaan dan pengelolaan proses belajar mengajar, para guru menggunakan beberapa metode pembelajaran dan dipadu dengan berbagai macam media pembelajaran, baik media yang biasa dijumpai di sekitar lingkungan sekolah seperti kelereng, timbangan, penggaris, atau media lainnya seperti proyektor khususnya di kelas atas. Adapun di kelas bawah, penggunaan media proyektor belum begitu diterapkan. Menurut Rusman, kegiatan pembelajaran di kelas merupakan inti penyelenggaraan pendidikan yang ditandai oleh adanya kegiatan pengelolaan kelas, penggunaan media dan sumber belajar, penggunaan metode dan strategi pembelajaran. Semua itu merupakan tugas dan tanggung jawab guru yang secara optimal dalam pelaksanaannya menuntut kemampuan guru (Rusman 2017, 184).

Kegiatan evaluasi atau penilaian guru dilakukan setiap kali tema pelajaran selesai. Ada juga guru yang melakukan evaluasi di setiap hari sesaat sebelum kepulangan sekolah. Hal ini dilakukan untuk mengukur kemampuan siswa sejauh mana pemahamannya terhadap apa yang telah disampaikan oleh guru. Ada pula penilaian yang diadakan serentak sepeti Penilaian Tengah Semester (PTS) dan Penilaian Akhir Sementer (PAS). Dan semua proses penilaian ini dilakukan untuk mengukur sejauh mana kemampuan siswa terhadap pembelajaran yang telah dilauinya. Menurut Gronlund \& Linn penilaian adalah suatu proses yang sistematis dan mencakup kegiatan mengumpulkan, menganalisis, serta menginterpretasikan informasi untuk menentukan sebarapa jauh seseorang mencapai tujuan pembelajaran yang ditetapkan (Gronlund and Linn 1990, 5). 
Sedangkan dalam kaitannya dengan pelaksanaan bimbingan belajar untuk peserta didik, guru melaksanakan bimbingan belajar tatkala pulang sekolah. Ada pula yang melakukan bimbingan di setiap saat dijumpai ada siswa yang mengalami kesulitan. Bimbingan belajar sebagaimana diungkapkan oleh Abu Ahmadi dan Ahmad Rohani bahwa bimbingan belajar merupakan seperangkat usaha bantuan kepada peserta didik agar dapat membuat pilihan, mengadakan penyesuaian, dan memecahkan masalah-masalah pendidikan dan pengajaran atau belajar yang dihadapinya. Artinya, bimbingan belajar adalah upaya guru pembimbing membantu siswa dalam mengatasi berbagai permasalahan belajar saat proses belajar mengajar berlangsung. (Ahmadi and Rohani 1991).

\section{E. Langkah-Langkah Peningkatan Kinerja Guru}

Di antara langkah-langkah yang dilakukan oleh kepala sekolah dalam meningkatkan kinerja guru adalah: a) Melibatkan warga sekolah dalam penyusunan visi, misi, dan program sekolah. b) Menyelenggarakan pelatihan-pelatihan yang sekiranya bisa meningkatkan kompetensi para guru dan karyawan. c) Mengikutsertakan guru dan karyawan dalam seminar, workshop, dan pelatihan yang berkaitan dengan kompetensi yang mereka butuhkan. d) Mengadakan studi banding ke lembaga lain yang lebih berpengalaman. e) Melobi pihak Yayasan untuk memberikan kenaikan gaji guru dan pegawai ke arah yang lebih layak. f) Memberikan reward, bonus, intensif, tunjangan, hadiah kepada guru dan karyawan yang memiliki kinerja baik sertam memeberikan sanksi/hukuman kepada guru dan karyawan yang melanggar.

\section{F. Penutup}

Gaya kepemimpinan yang dijalankan oleh kepala sekolah cenderung menggunakan gaya kepemimpinan transformasional. Hal ini terlihat dari temuan bahasan yang didapati bahwa indikator-indikator gaya kepemimpinan transformasional terdapat 
pada gaya kepemimpinan yang dilaksanakan oleh kepala sekolah. Dalam menjalankan peran kepemimpinannya, kepala sekolah tidak hanya sebagai seorang leader (pemimpin), namun menjalankan perannya juga sebagai seorang manajer, educator, supervisor, dan juga sebagai adminsitrator demi tercapainya tujuan pendidikan serta visi dan misi sekolah yang telah dirumuskan.

Kinerja guru dalam kaitannya tentang perencanaan proses belajar mengajar masih rendah. Namun, pada indikator kinerja yang berkaitan dengan penguasaan terhadap bahan ajar, kemampuan melaksanakan dan mengelola proses belajar mengajar, kemampuan melakukan evaluasi, serta kemampuan melaksanakan bimbingan belajar sudah cukup baik.

Langkah-langkah yang dilakukan kepala sekolah dalam meningkatkan kinerja guru di antaranya adalah dengan melibatkan warga sekolah dalam penyusunan visi, misi, dan program sekolah, mengadakan pelatihan-pelatihan yang dilakukan secara berkala, pendekatan personal, pembinaan, pemberian bonus, intensif, reward (hadiah), punishment (hukuman). Adapun kendala yang dihadapi oleh kepala sekolah dalam menjalankan langkah-langkah ini di antaranya adalah faktor latar belakang pendidikan para guru yang kebanyakan bukan dari dari jurusan pendidikan. Kendala yang kedua sifatnya lebih ke personal dan perbedaan karakter dari masing-masing guru.

\section{BIBLIOGRAPHY}

Ahmadi, Abu dan Ahmad Rohani. 1991. Bimbingan dan Konseling di Sekolah. Jakarta: Rineka Cipta.

Ancok, Djamaludin. 2012. Psikologi Kepemimpinan dan Inovasi. Jakarta: Erlangga.

Arikunto, Suharsimi. 2005. Prosedur Penelitian: Suatu Pendekatan Praktik. Jakarta: Rineka Cipta.

Effendi, Usman. 2011. Asas Manajemen. Jakarta: PT. Raja Grafindo. Gronlund \& Linn. 1990. Measurement and Evaluation in Teaching. 
New York: Mac Millan Publishing.

Liasrawati, Zakaria, dan Puspa Djuwita. 2017. "Peran Kepemimpinan Kepala Sekolah dalam Meningkatkan Kinerja Guru Bahasa Inggris." Jurnal Manajer Pendidikan 11(5). https://ejournal.unib.ac.id/index.php/manajerpendidikan/ article/view/3326.

Mudlofar, Ali. 2012. Aplikasi Pengembangan Kurikulum Tingkat Satuan Pendidikan dan Bahan Ajar dalam Pendidikan Islam. Jakarta: Rajawali Pers.

Mulyasa, H.E. 2001. Menjadi Kepala Sekolah Profesional. Bandung: PT. Remaja.

Mulyasa, H.E. 2013. Manajeman dan Kepemimpinan Kepala Sekolah. Jakarta: Bumi Aksara.

Muslich, Manshur. 2008. Kurikulum Tingkat Satuan Pendidikan. Jakarta: Bumi Aksara.

Nasir, Moh.1993. Metode Penelitian. Jakarta: Bumi Aksara.

Nasution. 2003. Metode Penelitian Naturalistik Kualitatif. Bandung: Tarsito.

Purwanti, Karina, Murniati A. R. dan Yusrizal. 2014. "Kepemimpinan Kepala Sekolah dalam Meningkatkan Kompetensi Guru Pada SMP Negeri 2 Simeulue Timur." Jurnal Ilmiah Didaktika 14(2). https://jurnal.ar-raniry.ac.id/index.php/didaktika/article/ view/510.

Purwanto, M. Ngalim. 2005. Administrasi dan Supervisi Pendidikan. Bandung: Rosdakarya.

Ramadoni, Wahyu, Kusmintardjo, dan Imron Arifin. 2016. "Kepemimpinan Kepala Sekolah dalam Upaya Peningkatan Kinerja Guru (Studi Multi Kasus di PAUD Islam Sabilillah dan SDN Tanjungsari 1 Kabupaten Sidoarjo." Jurnal Pendidikan: Teori, Penelitian, dan Pengembangan 1(8). http://journal. um.ac.id/index.php/jptpp/article/view/6620.

Rusman. 2017. Belajar dan Pembelajaran, Berorientasi Standar Proses Pendidikan. Jakarta: PT. Kharisma Putra Utama.

Samsudi dan Sadili. 2006. Manajemen Sumber Daya. Bandung: 
Mukhadasin; Aos Kuswandi

Pustaka Setia.

Soetjipto dan Raflis Kosasi. 2009. Profesi Keguruan. Jakarta: Rineka Cipta.

Suryabrata, Sumadi. Metode Penelitian. Jakarta: Rajawali.

Usman, Moh. Uzer. 2014. Menjadi Guru Profesional. Bandung: PT Remaja Rosdakarya.

Wahjosumidjo. 2007. Kepemimpinan Kepala Sekolah. Jakarta: Raja Grafindo Persada. 